Islah, et al/Jurnal Ekonomi Syariah Teori dan Terapan Vol. 6 No. 4 April 2019: 658-671; ANALISIS PENGUNJUNG DAN RETRIBUSI (PEDAGANG) KAWASAN WISATA RELIGI SUNAN GIRI TERHADAP PENDAPATAN ASLI DAERAH KABUPATEN GRESIK PERIODE 2011-2016

\title{
ANALISIS PENGUNJUNG DAN RETRIBUSI (PEDAGANG) KAWASAN WISATA RELIGI SUNAN GIRI TERHADAP PENDAPATAN ASLI DAERAH KABUPATEN GRESIK PERIODE 2011-20161
}

\author{
Muainul Islah \\ Departemen Ekonomi Syariah-Fakultas Ekonomi Dan Bisnis Universitas Airlangga \\ Email: muainull96@gmail.com
}

R. Mohammad Qudsi Fauzi

Departemen Ekonomi Syariah-Fakultas Ekonomi Dan Bisnis Universitas Airlangga Email: qudsifauzy1@gmail.com

\begin{abstract}
:
This study aims to determine the effect of Number of Visitors and Levies to Local Revenue partially and simultaneously. The sample used in this research is probability sampling that is monthly data of Sunan Giri (X1), Sunan Giri (X2) Retribution from Tourism and Culture Office of Gresik Regency. So that got 72 sample research. This research uses quantitative approach method and using multiple linear regression analysis. The results showed that some of the variable of the number of visitors did not have an effect on the Local Original Income, Retribution of merchants have a significant positive effect on the Original Revenue. Simultaneously variable Number of Visitor and Levy have significant effect to Original Income of Gresik Regency.

Keywords: Number of Sunan Giri Religious Tour Visitors, Sunan Giri Tourism Retribution, Gresik District Original Income.
\end{abstract}

\section{PENDAHULUAN}

Indonesia merupakan negara yang memiliki wilayah yang sangat luas dengan didukung sumber daya alam yang beraneka ragam yang berpotensi untuk diolah kekayaan alam yang dimilikinya serta dimanfaatkan untuk kesejahteraan penduduknya. Indonesia juga kaya akan budaya dan seni daerah, adat istiadat, peninggalan sejarah terdahulu dan tidak kalah menarik adalah keindahan panorama alamnya yang cukup potensial untuk dikembangkan dengan baik. Dalam sektor pariwisata juga bisa diandalkan untuk meningkatkan kesejahteraan ekonomi masyarakat dan pembangunan nasional (Hamjah, 2015). Indonesia merupakan negara dengan penduduk muslim terbesar di dunia yaitu sebesar 207.176.162 jiwa penduduk. Hal ini menunjukkan bahwa perkembangan pariwisata syariah di indonesia sudah mulai terkenal. Semakin banyaknya wisata di indonesia ini, maka secara otomatis banyak pengunjung nusantara maupun mancanegara yang ingin mengetahui keindahan dan kelestarian pariwisata yang berbasis syariah (bps.go.id).

Sektor pariwisata bisa menjadi sumber pendapatan yang sangat besar dan bisa dikantongi oleh pemerintah daerah jika dikembangkan secara serius. Menurut hitungan Kementrian Pariwisata dan Ekonomi Kreatif, setiap wisatawan mancanegara menghabiskan setidaknya Rp, 12,5 juta setiap kali berkunjung. Sektor

\footnotetext{
${ }^{1}$ Jurnal ini merupakan bagian dari skripsi Muainul Islah, NIM: 041311433025, yang diuji pada tanggal 15 Januari 2018.
} 
Islah, et al/Jurnal Ekonomi Syariah Teori dan Terapan Vol. 6 No. 4 April 2019: 658-671; ANALISIS PENGUNJUNG DAN RETRIBUSI (PEDAGANG) KAWASAN WISATA RELIGI SUNAN GIRI TERHADAP PENDAPATAN ASLI DAERAH KABUPATEN GRESIK PERIODE 2011-2016

pariwisata bisa memberikan dampak yang sangat baik dari segi perekonomian. Sifat pendapatan yang tunai, cepat, dan besar bisa dirasakan oleh berbagai sektor dan lapisan masyarakat.Bukan hanya pemerintahan daerah setempat yang merasakan, melainkan juga para pemain industri itu hingga para masyarakat yang berada di dalamnya (Salim, F, 2012).

Kabupaten Gresik merupakan tempat bagi Kawasan wisata religi Sunan Giri yang pada perjalanan sejarahnya menjadi tonggak sejarah syiar Islam di Jawa Timur. Taman wisata makam Sunan Giri merupakan salah satu obyek wisata yang terletak di kabupaten Gresik yang banyak menyediakan lapangan pekerjaan bagi masyarakat sekitarnya dengan bekerja sebagai pedagang atau penjual jasa seperti tukang parkir. Dalam berdagang, pedagang dalam mempromosikan jualannya biasanya menawar-nawarkan barangnya di sekeliling tempat untuk mendapatkan keuntungan yang banyak dari para wisatawan. Sehingga, dengan adanya wisata religi makam Sunan Giri mampu membantu perekonomian warga Gresik terutama di kecamatan Kebomas yang termasuk tempat makam Sunan Giri. Wisata religi Sunan Giri ini adalah wisata yang terus-menerus berkedatangan pengunjung baik pengunjung nusantara maupun mancanegara. Pengunjung nusantara maupun mancanegara yang menghabiskan waktu berwisata yang cukup lama maka, secara otomatis pengunjung akan mempengaruhi pajak dan retribusi kabupaten Gresik yang meningkat.seperti halnya penyewaan hotel atau makanan restoran. jika retribusi semakin meningkat maka akan mempengaruhi pendapatan asli daerah tersebut.

Tabel 1.

Pendapatan Asli Daerah Gresik

\begin{tabular}{|c|c|c|}
\hline Tahun & Target & Realisasi \\
\hline 2011 & $261,211,477,995.09$ & $273,975,992,140.13$ \\
\hline 2012 & $364,216,859,902.17$ & $427,580,866,657.55$ \\
\hline 2013 & $480,407,340,260.56$ & $502,767,029,904.17$ \\
\hline 2014 & $693,740,593,159.68$ & $700,587,792,877.47$ \\
\hline 2015 & $884,648,816,722.41$ & $799,884,870,103.03$ \\
\hline 2016 & $836,440,666,433.28$ & $715,480,938,191.16$ \\
\hline \multicolumn{3}{|c|}{ Berdasarkan data diatas bahwa }
\end{tabular}

pendapatan asli daerah kabupaten Gresik dari tahun 2011 sampai 2015 mengalami peningkatan yang signifikan. Tetapi, pada tahun 2016 pendapatan asli daerah cenderung menurun. Pendapatan asli daerah bukan hanya pajak daerah, retribusi daerah, bagian laba perusahaan dan penerimaan dinas-dinas daerah. Melainkan, keberadaan wisata religi Sunan Giri juga mampu meningkatkan pendapatan asli daerah (PAD) Kabupaten Gresik.Dengan banyaknya pengunjung yang datang ke wisata religi Sunan Giri, semakin lama wisatawan tinggal di suatu daerah tujuan wisata, maka semakin banyak pula vang yang di belanjakan di daerah tujuan wisata tersebut, dengan adanya kegiatan konsumtif baik dari wisatawan mancanegara maupun domestik, maka 
Islah, et al/Jurnal Ekonomi Syariah Teori dan Terapan Vol. 6 No. 4 April 2019: 658-671; ANALISIS PENGUNJUNG DAN RETRIBUSI (PEDAGANG) KAWASAN WISATA RELIGI SUNAN GIRI TERHADAP PENDAPATAN ASLI DAERAH KABUPATEN GRESIK PERIODE 2011-2016

akan memperbesar pendapatan dari sektor pariwisata suatu daerah.

\section{Pengunjung Sunan Giri}

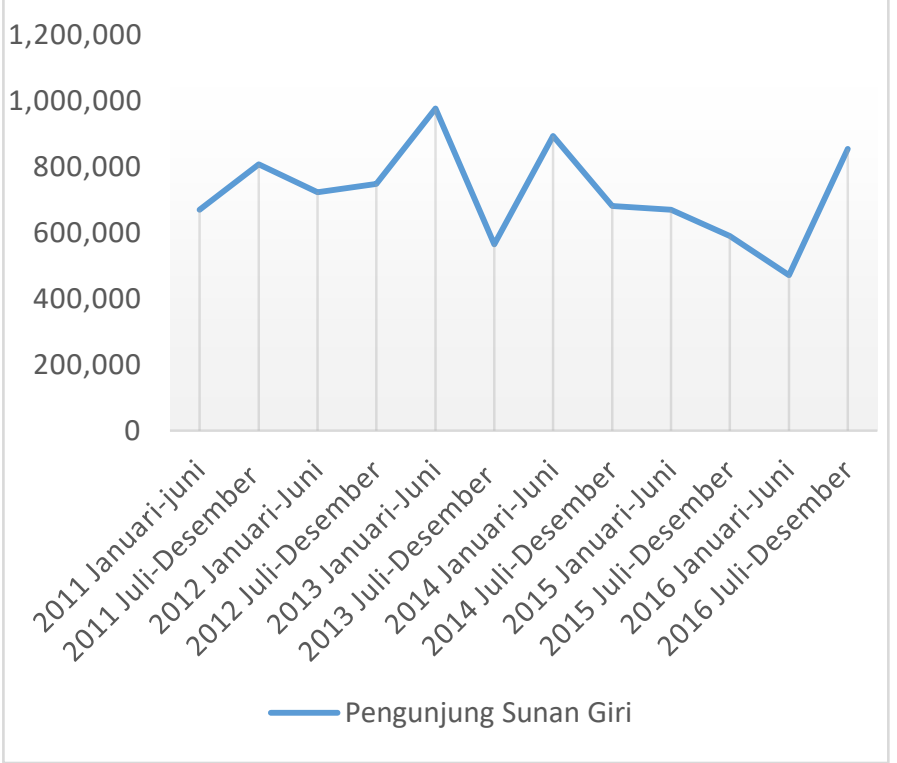

Gambar 1.

Pengunjung Sunan Giri

Berdasarkan Grafik pada gambar Jumlah Pengunjung pada periode 20112016 dapat dikatakan fluktuatif. Terjadi puncak pertumbuhan pada periode Januari - Juni 2013 sebesar 976407 pada periode berikutnya yaitu pada periode Juli - Desember 2013 turun sacara signifikan sebesar 564628 turun $42,1 \%$ dari periode sebelumnya.

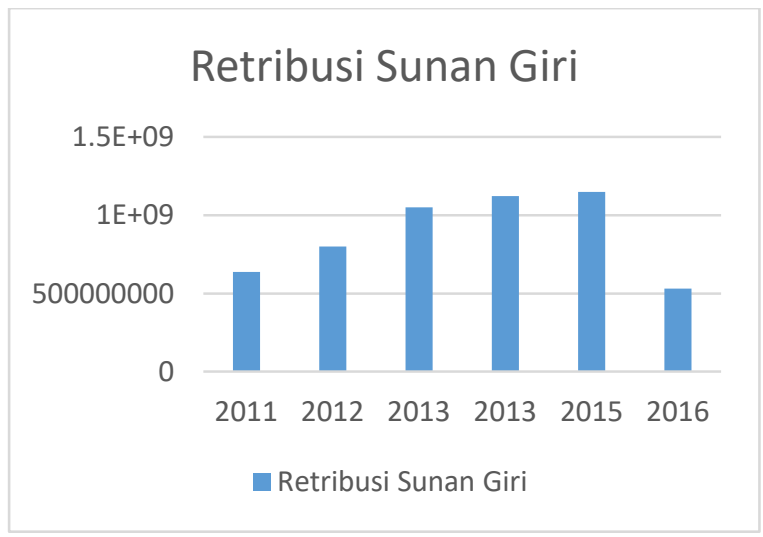

\section{Gambar 2.}

\section{Retribusi Sunan Giri}

Berdasarkan Grafik retribusi wisata Sunan Giri diatas terus mengalami pertumbuhan sampai tahun 2015. Namun pada tahun 2016 mengalami penurunan yang sangat signifikan sebesar 620 juta turun $53,9 \%$. Jenis retribusi yang diambil oleh peneliti adalah retribusi jasa usaha yaitu retribusi tempat rekreasi dan olahraga, lahan parkir dan kios-kios pedagang karena salah satu tempat rekreasi yang paling banyak diminati adalah Wisata Religi Makam Sunan Giri. Fenomena yang terjadi bahwa retribusi wisata Sunan Giri pada tahun 2011 dan 2012 dikelola oleh pihak/dinas tertentu. Tetapi, pada tahun 2013 sampai sekarang retribusi itu dikelolah oleh pihak pemerintah.Sehingga, pada tahun 2013 terjadi pembangunan wisata yang meliputi pelebaran lahan parkir kendaraan dan penataan lahan pedagang.Maka, peneliti tertarik untuk melakukan penelitian dengan judul "Analisis Pengunjung dan Retribusi Pedagang Kawasan Wisata Religi Sunan Giri Terhadap Pendapatan Asli Daerah (PAD) Kabupaten Gresik periode 20112016". Penelitian ini mengambil periode 2011-2016 karena pada tahun tersebut relevan dan tidak terlalu jauh untuk diteliti. Rumusan Masalah

1. Apakah secara simultan variabel jumlah pengunjung dan retribusi Pedagang kawasan wisata religi Sunan Giri berpengaruh terhadap Pendapatan 
Islah, et al/Jurnal Ekonomi Syariah Teori dan Terapan Vol. 6 No. 4 April 2019: 658-671; ANALISIS PENGUNJUNG DAN RETRIBUSI (PEDAGANG) KAWASAN WISATA RELIGI SUNAN GIRI TERHADAP PENDAPATAN ASLI DAERAH KABUPATEN GRESIK PERIODE 2011-2016

Asli Daerah (PAD) Kabupaten Gresik periode 2011-2016?

2. Apakah secara parsial variabel jumlah pengunjung dan retribusi Pedagang kawasan wisata religi Sunan Giri berpengaruh terhadap Pendapatan Asli Daerah (PAD) Kabupaten Gresik periode 2011-2016?

Tujuan Penelitian

1. Untuk mengetahui secara simultan adanya pengaruh signifikan jumlah pengunjung dan retribusi pedagang kawasan wisata religi Sunan Giri terhadap Pendapatan Asli Daerah (PAD) Kabupaten Gresik periode 20112016 ?

2. Untuk mengetahui secara parsial adanya pengaruh jumlah pengunjung dan retribusi pedagang kawasan wisata religi Sunan Giri terhadap Pendapatan Asli Daerah (PAD) Kabupaten Gresik Periode 2011-2016?

\section{LANDASAN TEORI}

Pariwisata berasal dari kata yakni, Pari dan Wisata. Pari diartikan sebagai banyak, berkali-kali, berputar-putar atau lengkap. Wisata dapat diartikan sebagai perjalanan atau bepergian yang dalam hal ini sinonim dengan kata travel; dalam bahasa Inggris. Maka, kata Pariwisata dapat diartikan sebagai perjalanan yang dilakukan berkali-kali atau berputar-putar dari suatu tempat ke tempat lain, yang dalam bahasa Inggris disebut tour (Yoeti, 2001). Pariwisata dapat juga diartikan sebagai kegiatan melakukan perjalanan dengan tujuan mendapatkan kenikmatan, mencari kepuasan, mengetahui sesuatu, memperbaiki kesehatan, menikmati olahraga atau istirahat, menunaikan tugas, berziarah, dan lain-lain, pariwisata bukanlah merupakan kegiatan yang baru saja dilakukan oleh manusia masa kini.

Menurut Syahriza, (2014) Pariwisata dalam bahasa Arab disebut dengan rihlah yang artinya perjalanan. selain kata rihlah, perjalanan dalam bahasa Arab juga diungkapkan dengan istilah lain seperti kata safara (سافر) dan sara (سار ). Kata safara dalam al-Qur'an mempunyai beragam makna yaitu (Syahriza, 2014).

1. Membuka dan membersihkan debu.

2. Menunjukan warna seperti dalam surat Al-Muddatstsir: 34.

3. Melakukan perjalanan sebagaimana dalam surat Al-Nisa`: 43.

4. Bermakna kitab seperti yang diungkapkan dalam surat Al-Jumu'ah: 5.

Adapun kata sara dalam al-Qur'an bermakna (Syahriza, R. 2014).

1. Perintah, ikhtiar (usaha), dan keinginan untuk melakukan perjalanan seperti pada surat Yunus: 22

2. Bermakna sekelompok orang seperti pada surat Yusuf: 19

3. Bermakna menundukkan sesuatu yang ingin dicapai seperti menundukkan gunung sebagaimana yang diungkapkan pada surat al-Takwir: 3

4. Kondisi secara naluriah (gharizah) atau yang diupayakan (muktasabiyah) yang 
Islah, et al/Jurnal Ekonomi Syariah Teori dan Terapan Vol. 6 No. 4 April 2019: 658-671; ANALISIS PENGUNJUNG DAN RETRIBUSI (PEDAGANG) KAWASAN WISATA RELIGI SUNAN GIRI TERHADAP PENDAPATAN ASLI DAERAH KABUPATEN GRESIK PERIODE 2011-2016

ada pada diri seseorang sebagaimana diungkapkan pada surat Thaha: 21 .

Diriwayatkan oleh Ibnu Hani dari Ahmad bin Hanbal, beliau ditanya tentang seseorang yang bepergian atau bermukim di suatu kota, mana yang lebih anda sukai? Beliau menjawab: "Wisata tidak ada sedikit pun dalam Islam, tidak juga perilaku para nabi dan orang-orang saleh." (Talbis Iblis, 340). Ibnu Rajab mengomentari perkataan Imam Ahmad dengan mengatakan: "Wisata dengan pemahaman ini telah dilakukan oleh sekelompok orang yang dikenal suka beribadah dan bersungguh-sungguh tanpa didasari ilmu. Di antara mereka ada yang kembali ketika mengetahui hal itu." (Fathul-Bari, karangan Ibnu Rajab, 1/56)

Kamudian Islam datang untuk meninggikan pemahaman wisata dengan mengaitkannya dengan tujuan-tujuan yang mulia (Munajjed, 2010). Di antaranya:

1. Menghubungkan wisata dengan ibadah, Sehingga mengharuskan adanya safar atau wisata untuk menunaikan salah satu rukun dalam agama yaitu haji pada bulan-bulan tertentu.

2. Demikian pula, dalam pemahaman Islam, wisata dikaitkan dengan ilmu dan pengetahuan. Pada permulaan Islam, telah ada perjalanan sangat agung dengan tujuan mencari ilmu dan menyebarkannya.

3. Wisata dalam rangka mengambil pelajaran dan peringatan. Dalam Al-
Qur'an terdapat perintah untuk berjalan di muka bumi di beberapa tempat (al-An'am:11 dan al-Naml: 69).

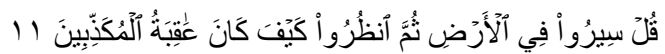
Qul sirú fil-ardi summanzurú̄ kaifa kāna áqibatul-mukazzibin

Katakanlah: "Berjalanlah di muka bumi, kemudian perhatikanlah bagaimana kesudahan orang-orang yang mendustakan itu". (An- An'am ayat 11). Kemudian dilanjutkan surat An Naml ayat 69 yang berbunyi:

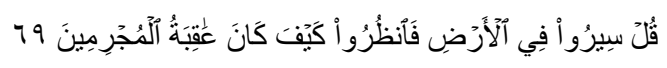
qul siru fil-ardi fanzurū kaifa kāna áquibatulmujrimin

Katakanlah: "Berjalanlah kamu (di muka) bumi, lalu perhatikanlah bagaimana akibat orang-orang yang berdosa. (AlNaml ayat 69).

4. Wisata dalam rangka berdakwah kepada Allah Ta'ala seperti yang dilakukan oleh para Nabi dan Rasul yang telah menyebar ke ujung dunia untuk mengajarkan kebaikan kepada manusia, mengajak mereka kepada kalimat yang benar.

5. Safar atau wisata untuk merenungi keindahan ciptaan Allah Ta'la, menikmati indahnya alam nan agung sebagai pendorong jiwa manusia untuk menguatkan keimanan terhadap keesaan Allah dan memotivasi menunaikan kewajiban hidup sebagaimana disebutkan Allah dalam surat (Al - Ankabut: 20).

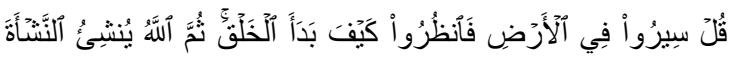

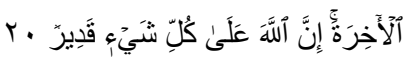


Islah, et al/Jurnal Ekonomi Syariah Teori dan Terapan Vol. 6 No. 4 April 2019: 658-671; ANALISIS PENGUNJUNG DAN RETRIBUSI (PEDAGANG) KAWASAN WISATA RELIGI SUNAN GIRI TERHADAP PENDAPATAN ASLI DAERAH KABUPATEN GRESIK PERIODE 2011-2016

qul sirū fil-ardi fanzurū kaifa bada 'alkhalqa summallah̄u yunsyi 'un-nasy'atalaḱkirah, innallaha ála kulli syai ing qadir Katakanlah: "Berjalanlah di (muka) bumi, Maka perhatikanlah bagaimana Allah menciptakan (manusia) dari permulaannya, kemudian Allah SWT menjadikannya sekali lagi. Sesungguhnya Allah Maha Kuasa atas segala sesuatu.

Berdasarkan penjelasan diatas dapat ditarik kesimpulan bahwa didalam ajaran Islam pun telah diterangkan secara jelas tentang diperbolehkannya pariwisata ke berbagai tempat di seluruh dunia dengan maksud dan tujuan tertentu yang di antaranya adalah:

1. Untuk beribadah seperti haji dan umrah

2. Untuk menambah wawasan dan pengetahuan agama seperti ke tempat yang menyimpan sejarah tentang Islam

3. Untuk berdakwah dan menyiarkan agama Islam

4. Pergi ke beberapa tempat untuk melihat berbagai peninggalan sebagai nasehat, pelajaran dan manfaat lainnya

5. Menikmati indahnya alam yang indah sebagai pendorong jiwa manusia untuk menguatkan keimanan terhadap keesaan Allah SWT dan memotivasi menunaikan kewajiban hidup.

\section{Wisata Syariah}

Wisata Syariah atau Halal Toursim adalah salah satu sistem pariwisata yang di peruntukan bagi wisatawan Muslim yang pelaksanaanya mematuhi aturan
Syariah. Dalam hal ini hotel yang mengusung prisip syariah tidak melayani minuman beralkohol dan memiliki kolam renang dan fasilitas spa terpisah untuk pria dan wanita. (Arby.Ikhsan, 2017)

\section{Wisata Religi}

Pengertian wisata adalah suatu perjalanan sementara yang dilakukan oleh seseorang maupun sekumpulan orang untuk mengunjungi tempat yang menarik, unik, dan tentunya memiliki nilai histori. Terkait dengan nilai histori yang terkandung pada tempat wisata tersebut dapat dimanfaatkan untuk memdapatkan dan memperdalam ilmu pengetahuan. Pada masa lalu wisata religi sering dikaitkan dengan kebiasaan atau tradisi dan budaya sekumpulan masyarakat, namun dalam perkembangannya wisata religi sekarang milik semua kalangan dari kalangan bawah hingga kalangan atas. Wisata religi adalah wisata yang sedikit banyak dikaitkan dengan agama, sejarah, adat istiadat, kepercayaan umat atau kelompok dalam masyarakat. Wisata ini banyak dilakukan perorangan atau kelompok ke tempat-tempat suci, ke makam orang-orang besar atau pemimpin yang diagungkan, ke bukit atau gunung yang dikeramatkan, ke tempat pemakaman tokoh atau pemimpin sebagai manusia ajaib penuh legenda(Pendit, S, 2002:42).

\section{Jumlah Kunjungan Wisatawan}

Banyaknya wisatawan yang berkunjung ke suatu daerah tujuan wisata 
Islah, et al/Jurnal Ekonomi Syariah Teori dan Terapan Vol. 6 No. 4 April 2019: 658-671; ANALISIS PENGUNJUNG DAN RETRIBUSI (PEDAGANG) KAWASAN WISATA RELIGI SUNAN GIRI TERHADAP PENDAPATAN ASLI DAERAH KABUPATEN GRESIK PERIODE 2011-2016

tertentu menjadi salah satu bukti bahwa daerah tersebut mempunyai daya tarik wisata yang besar. Ada beberapa ahli yang mencoba untuk mendefinisikan kata wisatawan salah satunya adalah Sammeng. Wisatawan menurut Sammeng, (2001). yaitu:

"Orang yang melakukan perjalanan atau kunjungan sementara secara sukarela ke suatu tempat di luar lingkungan tempat tinggalnya sehari-hari untuk maksud tertentu dan tidak memperoleh penghasilan tetap di tempat yang dikunjunginya".

Pacific Area Travel Association memberi batasan bahwa wisatawan sebagai orang-orang yang sedang mengadakan perjalanan dalam jangka waktu 24 jam dan maksimal 3 bulan di dalam suatu negeri yang bukan negeri di mana biasanya ia tinggal, mereka ini meliputi:

1. Orang-orang yang sedang mengadakan perjalanan untuk bersenang-senang, untuk keperluan pribadi, untuk keperluan kesehatan.

2. Orang-orang yang sedang mengadakan perjalanan untuk tujuan pertemuan, konferensi, musyawarah atau sebagai utusan berbagai badan/organisasi.

3. Orang-orang yang sedang mengadakan perjalanan dengan maksud bisnis pejabat pemerintahan dan militer beserta keluarganya yang di tempatkan di negara lain tidak termasuk kategori ini, tetapi bila mereka mengadakan perjalanan ke negeri lain, maka dapat digolongkan wisatawan (Pendit, 1994).

\section{Retribusi Obyek Wisata}

Pendapatan objek pariwisata adalah merupakan sumber penerimaan obyek pariwisata yang berasal dari retribusi karcis masuk, retribusi parkir dan pendapatan lain-lain yang sah berasal dari obyek pariwisata tersebut. Menurut UU No. 34 tahun 2000 tentang perubahan UU No. 18 tahun 1997 bahwa Pajak Daerah dan Retribusi Daerah merupakan salah satu sumber pendapatan Daerah yang penting untuk membiayai penyelenggaraan pemerintahan Daerah dan pembangunan Daerah.

\section{Konsep Pendapatan Asli Daerah}

Menurut Mardiasmo (2000:132), "pendapatan asli daerah adalah penerimaan yang diperoleh dari sektor pajak daerah, retribusi daerah, hasil perusahaan milik daerah, hasil pengeloalaan kekayaan daerah yang dipisahkan, dan lain-lain pendapatan asli daerah yang sah".

$$
\text { Menurut Halim }
$$

pendapatan asli daerah merupakan semua penerimaan daerah yang berasal dari sumber ekonomi asli daerah. Menurut pasal 6 UU No. 33 Tahun 2004 ayat 1 dan 2 menyatakan bahwa sumber pendapatan daerah terdiri dari Pendapatan Asli Daerah, Bagi Hasil Pajak dan Bukan Pajak. Pendapatan Asli Daerah sendiri terdiri atas : pajak daerah, retribusi daerah, hasil pengolahan kekayaan 
Islah, et al/Jurnal Ekonomi Syariah Teori dan Terapan Vol. 6 No. 4 April 2019: 658-671; ANALISIS PENGUNJUNG DAN RETRIBUSI (PEDAGANG) KAWASAN WISATA RELIGI SUNAN GIRI TERHADAP PENDAPATAN ASLI DAERAH KABUPATEN GRESIK PERIODE 2011-2016

daerah yang dipisahkan, serta lain-lain PAD yang sah. Klasifikasi PAD yang terbaru berdasarkan Permendagri Nomor 13 Tahun 2006 terdiri dari: Pajak daerah, retribusi daerah, hasil pengelolaan daerah yang dipisahkan, dan lain-lain pendapatan asli daerah yang sah.

Menurut Samsubar Saleh (2003) pendapatan daerah merupakan suatu komponen yang sangat menentukan berhasil tidaknya kemandirian pemerintah Kabupaten/Kota dalam rangka otonomi daerah saat ini. Salah satu komponen yang sangat diperhatikan dalam menentukan tingkat kemandirian daerah dalam rangka otonomi daerah adalah sektor Pendapatan Asli Daerah.

Menurut Mangkosubroto (2001) menyatakan bahwa pada umumnya penerimaan pemerintah diperlukan untuk membiayai pengeluaran pemerintah. Pada umumnya penerimaan pemerintah dapat dibedakan antara penerimaan pajak dan bukan pajak. Penerimaan bukan pajak, misalnya adalah penerimaan pemerintah yang berasal dari pinjaman pemerintah, baik pinjaman yang berasal dari dalam negeri maupun pinjaman pemerintah yang berasal dari lvar negeri.

Pendapatan Asli Daerah secara garis besar terdiri dari komponenkomponen (Sutrisno PH, 1988:187 - 193):

1. Pajak Daerah

2. Retribusi Daerah

3. Bagian laba Badan Usaha Milik Daerah

4. Penerimaan dari dinas-dinas daerah
5. Penerimaan lain-lain

Batasan pengertian mengenai pendapatan asli daerah (Sutrisno P.H, 1988: 187-193) ialah merupakan suatu pendapatan yang menunjukkan kemampuan suatu daerah dalam menghimpun sumber-sumber dana untuk membiayai kegiatan daerah. Jadi pengertian pendapatan asli daerah dapat dikatakan sebagai pendapatan rutin dari usaha-usaha pemerintah daerah dalam memanfaatkan potensi-potensi sumber keuangannya untuk membiayai tugas-tugas dan tanggung jawabnya. Uraian secara rinci tentang komponenkomponen pendapatan asli daerah adalah : pajak daerah, retribusi daerah, Bagian Laba Perusahaan Daerah Penerimaan Dinas-Dinas Daerah dan Penerimaan Lain-lain.

Berdasarkan penjelasan latar belakang, rumusan masalah, tujuan penelitian, tinjauan pustaka, maka hipotesis dalam penelitian ini adalah sebagai berikut:

H1: Jumlah Wisatawan berpengaruh positif terhadap Pendapatan Asli Daerah (PAD). H2: Retribusi berpengaruh positif terhadap Pendapatan Asli Daerah (PAD)

H3: Jumlah Pengunjung dan Retribusi berpengaruh terhadap Pendapatan Asli Daerah (PAD).

\section{METODE PENELITIAN}

Pendekatan yang digunakan dalam penelitian ini adalah pendekatan kuantitatif setiap jawaban atas rumusan 
Islah, et al/Jurnal Ekonomi Syariah Teori dan Terapan Vol. 6 No. 4 April 2019: 658-671; ANALISIS PENGUNJUNG DAN RETRIBUSI (PEDAGANG) KAWASAN WISATA RELIGI SUNAN GIRI TERHADAP PENDAPATAN ASLI DAERAH KABUPATEN GRESIK PERIODE 2011-2016

masalah yang dibuat dan melakukan pengujian atas hipotesis yang dibentuk.

Populasi

Menurut Anshori dan Iswati (2009:92), populasi adalah wilayah generalisasi yang terdiri atas subjek yang mempunyai kualitas dan karakteristik tertentu yang ditetapkan oleh peneliti untuk dipelajari dan kemudian ditarik kesimpulannya. Populasi pada penelitian ini adalah Pendapatan Asli Daerah (PAD) periode 2011-2016.

\section{Sampel}

Sampel bagian dan jumlah dan karakteristik yang dimiliki oleh populasi (Ansori dan Iswati 2009:24).Metode penelitian sampel dalam penelitian inimenggunakan probability sampling, yaitu teknik pengambilan sampel yang boleh memberi kesempatan yang sama untuk setiap populasi untuk dipilih menjadi sampel. Sampel pada penelitian ini adalah jumlah pengunjung dan retribusi pedagang wisata Sunan Giri.

Teknik analisis dan pengolahan data yang dilakukan peneliti pada penelitian ini adalah menggunakan teknik analisis regresi linier berganda dan pengolahan datanya menggunakan SPSS. Teknik analisis ini untuk mengetahui hubungan antara variable endogen da neksogen.

IV. HASIL DAN PEMBAHASAN

Analisis Model dan Pengujian Hipotesis

Uji Asumsi Klasik

Uji Normalitas
Tabel 2.

Hasil Uji Kolmogorov-Smirnov

\begin{tabular}{|l|l|}
\hline & $\begin{array}{l}\text { Unstandarized } \\
\text { Residual }\end{array}$ \\
\hline $\mathrm{N}$ & 72 \\
\hline $\begin{array}{l}\text { Kolmogorov- } \\
\text { Smirnov Z }\end{array}$ & 0,166 \\
\hline $\begin{array}{l}\text { Asymp. Sig. } \\
\text { (2-tailed) }\end{array}$ & 0,000 \\
\hline
\end{tabular}

Sumber : Lampiran 2, Hasil Uji SPSS (Data Diolah)

Berdasarkan hasil uji Kolmogorovsmirnov dapat diketahui nilai sig. (2-tailed) sebesar 0,000 dengan nilai Kolmogorovsmirnov Z 0,166. Data dapat dikatakan berdistribusi normal apabila nilai signifikansi menunjukkan lebih dari 0,05, sedangkan dari hasil Kolmogorov-smirnov diatas menunjukkan nilai sig. (2-tailed) sebesar $0,000<0,005$ dengan $\mathrm{N}$ sebesar 72 . Maka dapat dikatakan data tersebut tidak berdistribusi secara normal. Hal yang dapat dilakukan adalah pada penelitian ini distribusi normal 666abl terpenuhi setelah melakukan outlier data yang terdapat di 666able casewise pada SPSS yaitu 25, 29, 30, 33, 67. Berikut adalah hasil uji Kolmogorov-Smirnov setelah melakukan outlier.

Tabel 3.

Hasil Uji Kolmogorov-Smirnov

\begin{tabular}{|l|l|}
\hline & $\begin{array}{l}\text { Unstandarized } \\
\text { Residual }\end{array}$ \\
\hline $\mathrm{N}$ & 67 \\
\hline $\begin{array}{l}\text { Kolmogorov- } \\
\text { Smirnov } \mathrm{Z}\end{array}$ & 1,123 \\
\hline Asymp. Sig. (2- & 0,160 \\
\hline
\end{tabular}


Islah, et al/Jurnal Ekonomi Syariah Teori dan Terapan Vol. 6 No. 4 April 2019: 658-671; ANALISIS PENGUNJUNG DAN RETRIBUSI (PEDAGANG) KAWASAN WISATA RELIGI SUNAN GIRI TERHADAP PENDAPATAN ASLI DAERAH KABUPATEN GRESIK PERIODE 2011-2016

\begin{tabular}{|l|l|}
\hline tailed) & \\
\hline Sumber : Hasil Uji SPSS (Data Diolah)
\end{tabular}

Berdasarkan Tabel 4.2 dapat diperoleh nilai Kolmogorov-Smirnov 1,123 dengan tingkat signifikansi 0,160. Hal tersebut menunjukkan bahwa data terdistribusi secara normal.

Hasil Uji Normalitas Menggunakan Grafik Normal Probability Plot

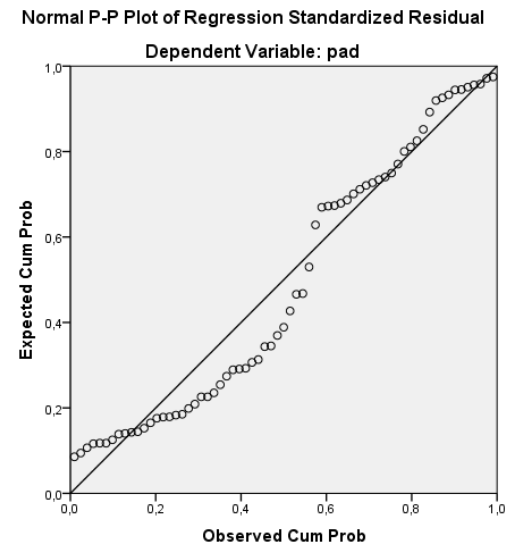

Sumber : Hasil Uji SPSS (Data Diolah)

Gambar 3.

\section{Normal Probability Plot}

Hasil pengujian pada grafik Normal Probability plot diatas, menunjukkan bahwa terdapat titik-titik data yang menyebar pada sekitar garis diagonal dan bergerak mengikuti garis diagonal. Maka, dapat disimpulkan Grafik P-P Plot dalam penelitian ini telah berdistribusi secara normal.

\section{Uji Multikolinieritas}

Tabel 4.

Hasil Uji Multikolinieritas

\begin{tabular}{|l|l|l|l|}
\hline \multirow{4}{*}{ Variabel } & \multicolumn{2}{|l|}{$\begin{array}{l}\text { Collinearity } \\
\text { Statistics }\end{array}$} & \multirow{2}{*}{ Kesimpulan } \\
\cline { 2 - 3 } & $\begin{array}{l}\text { Toleranc } \\
\mathrm{e}\end{array}$ & VIF & \\
\hline
\end{tabular}

\begin{tabular}{|l|l|l|l|}
\hline $\begin{array}{l}\text { Jumlah } \\
\text { Pengunjun } \\
\mathrm{g}\end{array}$ & 0,991 & $\begin{array}{l}1,00 \\
9\end{array}$ & $\begin{array}{l}\text { Bebas } \\
\text { Multikolinierita } \\
\mathrm{s}\end{array}$ \\
\hline Retribusi & 0,991 & $\begin{array}{l}1,00 \\
9\end{array}$ & $\begin{array}{l}\text { Bebas } \\
\text { Multikolinierita } \\
\mathrm{s}\end{array}$ \\
\hline
\end{tabular}

Sumber:Hasil Uji SPSS (Data diolah).

Dengan demikian variabel yang saya gunakan dalam penelitian ini yaitu Jumlah Pengunjung $\left(X_{1}\right)$, Retribusi Pedagang $\left(X_{2}\right)$. Seperti yang dicantum pada tabel 4.3 dapat diketahui bahwa nilai VIF pada variabel Jumlah Pengunjung dan Retribusi Pedagang adalah 1,009 <10. Hal ini dapat disimpulkan bahwa pada model regresi tidak terjadi Multikolinieritas.

\section{Uji Heteroskedastisitas}

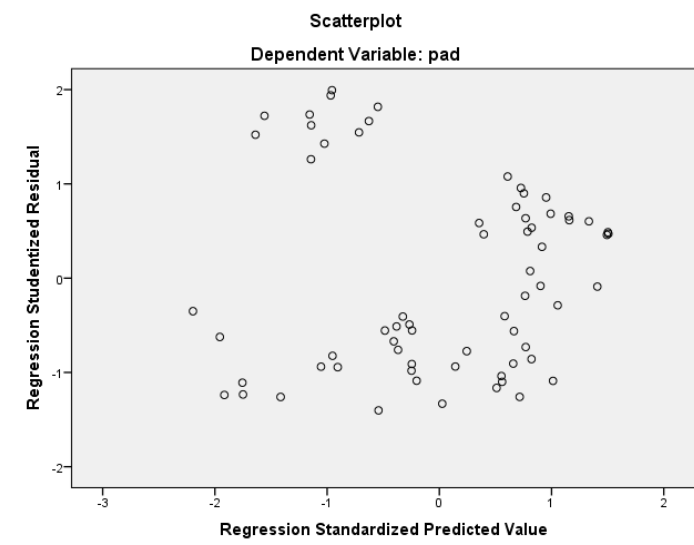

Sumber: Hasil Uji SPSS (Data Diolah)

Gambar 4.

\section{Hasil Uji Heteroskedastisitas}

Pada Gambar di atas dapat diketahui bahwa titik-titik dara menyebar secara acak di atas dan dibawah angka 0 pada sumbu $Y$ serta tidak membentuk pola yang teratur seperti bergelombang. Pada gambar dibawah, titik-titik membentuk pola yang menyebar lalu kemudian menyempit. Dapat diartikan bahwa 
Islah, et al/Jurnal Ekonomi Syariah Teori dan Terapan Vol. 6 No. 4 April 2019: 658-671; ANALISIS PENGUNJUNG DAN RETRIBUSI (PEDAGANG) KAWASAN WISATA RELIGI SUNAN GIRI TERHADAP PENDAPATAN ASLI DAERAH KABUPATEN GRESIK PERIODE 2011-2016

penelitian ini terbebas dari heterokedastisitas.

Uji Autokorelasi

Tabel 5.

Uji Durbin Watson

\begin{tabular}{|l|l|l|}
\hline Model & $\begin{array}{l}\text { Nilai } \\
\text { Durbin- } \\
\text { Watson }\end{array}$ & Kesimpulan \\
\cline { 2 - 3 } 1 & 1,132 & $\begin{array}{l}\text { Bebas } \\
\text { Autokorelasi }\end{array}$ \\
\hline
\end{tabular}

Sumber:Hasil Uji SPSS (Data diolah).

Apabila angka Durbin-Watson di antara -2 sampai +2 dapat dikatakan tidak terjadi autokorelasi Berdasarkan tabel 4,4 dapat diketahui bahwa nilai Durbin-Watson sebesar 1,132. Maka nilai Durbin-Watson berada pada $-2<1,132<2$ jadi dapat disimpulkan bahwa pada penelitian ini tidak terjadi autokorelasi.

\section{Uji Hipotesis}

Uji † (secara parsial)

Tabel 6.

Hasil Uji †

\begin{tabular}{|l|l|l|}
\hline Model & t-hitung & Sig. \\
\hline $1 \quad$ (Constant) & 4,571 & 0,000 \\
Jumlah & $-1,488$ & 0,142 \\
$\begin{array}{l}\text { Pengunjung (X1) } \\
\text { Retribusi (X2) }\end{array}$ & 5,489 & 0,000 \\
\hline
\end{tabular}

Sumber: Hasil Uji SPSS (Data Diolah).

Dependent Variable: Jumlah Pengunjung, Retribusi

Berdasarkan tabel 4.5 di atas dapat disimpulkan bahwa.

1. Dengan nilai $\dagger$ statistik pada variabel Jumlah Pengunjung sebesar -1,488 dengan nilai signifikansi sebesar 0,142 lebih besar dari 0,05 maka Hoditerima dan $\mathrm{Ha}$ ditolak, yang artinya bahwa variabel Jumlah Pengunjung tidak berpengaruh signifikan terhadap pendapatan asli daerah Kabupaten Gresik.

2. Dengan nilai $t$ hitung pada variabel Retribusi Pedagang sebesar 5,489 lebih besar dari $\dagger$ tabel sebesar 1,997 ${ }^{\dagger}$ hitung 5,489>1,997) dengan nilai signifikansi sebesar 0,000 lebih kecil dari 0,05 maka dapat disimpulkan bahwa Hoditolak dan Ha diterima, yang artinya bahwa variabel Retribusi Pedagang berpengaruh signifikan terhadap pendapatan asli daerah Kabupaten Gresik.

\section{Uji F (secara bersama-sama)}

Tabel 7.

Hasil uji F

\begin{tabular}{|c|c|c|c|c|c|}
\hline Model & SS & $\begin{array}{l}\text { d } \\
\text { f }\end{array}$ & MS & $F$ & Sig. \\
\hline $\begin{array}{l}1 \\
\text { Regres } \\
\text { sion }\end{array}$ & $\begin{array}{l}9964.03 \\
7\end{array}$ & 2 & $\begin{array}{l}2,64 \\
21\end{array}$ & $\begin{array}{l}15,5 \\
42\end{array}$ & $\begin{array}{l}.000 \\
b\end{array}$ \\
\hline $\begin{array}{l}\text { Residu } \\
\text { al }\end{array}$ & $\begin{array}{l}2774.60 \\
0 \\
12738.6 \\
37\end{array}$ & 4 & $\begin{array}{l}1,70 \\
20\end{array}$ & & \\
\hline
\end{tabular}

a. Dependent Variable: Pendapatan Asli Daerah

a. Predictors: (Constant), Retribusi, Jumlah pengunjung

Sumber: Hasil Uji SPSS (Data Diolah). Berdasarkan tabel diatas menunjukkan bahwa variabel independen yaitu Jumlah Pengunjung dan Retribusi memberi hasil Fhitung 
Islah, et al/Jurnal Ekonomi Syariah Teori dan Terapan Vol. 6 No. 4 April 2019: 658-671; ANALISIS PENGUNJUNG DAN RETRIBUSI (PEDAGANG) KAWASAN WISATA RELIGI SUNAN GIRI TERHADAP PENDAPATAN ASLI DAERAH KABUPATEN GRESIK PERIODE 2011-2016

sebesar 15,542 (F hitung 15,542 > F tabel $3,13)$ dengan tingkat signifikansi lebih kecil dari $5 \%$ yaitu sebesar 0,000. Berdasarkan hasil tersebut maka dapat dinyatakan bahwa $H_{a}$ diterima dan Ho ditolak, sehingga dapat disimpulkan bahwavariabel Jumlah Pengunjung ( $\left.X_{1}\right)$ dan Retribusi $\left(\mathrm{X}_{2}\right)$ berpengaruh secara simultan (bersama-sama) terhadap pendapatan asli daerah (Y) Kabupaten Gresik periode 2011-2016.

Uji $\mathbf{R}^{2}$

Tabel 8.

Koefisien Determinasi Adjusted $\mathbf{R}^{2}$ Model Summary

\begin{tabular}{|c|c|c|c|c|}
\hline Mode & R & $\begin{array}{l}\text { R- } \\
\text { Squar } \\
\text { e }\end{array}$ & $\begin{array}{l}\text { Adjuste } \\
\text { d R } \\
\text { Square }\end{array}$ & $\begin{array}{l}\text { Std. } \\
\text { Error of } \\
\text { the } \\
\text { Estimat } \\
\text { e }\end{array}$ \\
\hline 1 & $\begin{array}{l}, 57 \\
2\end{array}$ & ,327 & ,306 & 1,30000 \\
\hline
\end{tabular}

a. Predictor:

(Constant)

Jumlah

Pengunjung dan Retribusi

b. Dependent Variabel: Pendapatan Asli Daerah

Sumber: Hasil Uji SPSS (Data Diolah) Berdasarkan Tabel 4.7, uji $R^{2}$ menunjukkan nilai sebesar 0,327 yang berarti bahwa variasi variabel dependen yaitu pendapatan asli daerah dapat dijelaskan oleh variabel independen yaitu Jumlah Pengunjung dan Retribusi Pedagang sebesar 32\%, sedangkan sisanya sebesar $68 \%$ dijelaskan oleh variabel lain yang tidak dibahas pada penelitian ini. Variabel Jumlah Pengunjung dan Retribusi Pedagang Sunan Giri memberikan porsi yang cenderung lebih sedikit untuk menjelaskan variabel Pendapatan Asli Daerah dibanding faktorfaktor lainnya.

\section{SIMPULAN DAN SARAN \\ Kesimpulan}

Berdasarkan hasil analisis dan pengujian dalam penelitian Pengaruh Jumlah Pengunjung dan Retribusi Pedagang Kawasan Wisata Religi Sunan Giri Terhadap Pendapatan Asli Daerah (PAD) Kabupaten Gresik periode 20112016, maka diperoleh kesimpulan sebagai berikut :

1. Variabel jumlah pengunjung wisata Sunan Giri (X1) tidak berpengaruh secaraparsial terhadap pendapatan asli daerah (PAD) Kabupaten Gresik periode 2011-2016.

2. Variabel retribusi pedagang kawasan wisata Sunan Giri (X2) berpengaruh signifikan positif secara parsial terhadap pendapatan asli daerah (PAD) Kabupaten Gresik periode 20112016.

3. Variabel jumlah pengunjung dan retribusi pedagang kawasan wisata religi Sunan Giri (X1, X2) secara simultan berpengaruh positif secara signifikan terhadap pendapatan asli daerah (PAD) Kabupaten Gresik periode 20112016.

Saran

Saran yang direkomendasikan setelah penelitian Pengaruh Jumlah Pengunjung dan Retribusi Pedagang 
Islah, et al/Jurnal Ekonomi Syariah Teori dan Terapan Vol. 6 No. 4 April 2019: 658-671; ANALISIS PENGUNJUNG DAN RETRIBUSI (PEDAGANG) KAWASAN WISATA RELIGI SUNAN GIRI TERHADAP PENDAPATAN ASLI DAERAH KABUPATEN GRESIK PERIODE 2011-2016

Kawasan Wisata Religi Sunan Giri Terhadap Pendapatan Asli Daerah (PAD) Kabupaten Gresik periode 2011-2016 adalah sebagai berikut:

1. Untuk Pemerintah sebagai pembuat regulasi diharapkan terus melakukan regulasi dan penyempurnaan dalam menstabilkan pariwisata syariah dan juga harus gencar melakukan promosi untuk destinasi wisata syariah di Indonesia khususnya lokasi wisata religi Sunan Giri Kabupaten Gresik.

2. Untuk Dinas Pariwisata dan Kebudayaan Dalam rangka mengoptimalkan pengelolaan potensi pariwisata menuju peningkatan pengembangan pariwisata, perlu melibatkan pihak-pihak terkait untuk bersama-sama mendorong kebijakan pengembangan pariwisata syariah Kabupaten Gresik.

3. Untuk penelitian selanjutnya

Saran kepada peneliti yang akan datang, penelitian ini dapat digunakan sebagai acuan atau bahan referensi, khususnya dalam lingkup pariwisata syariah. dikarena penelitian ini hanya menggunakan dua variabel, maka untuk penelitian selanjutnya disarankan menggunakan lebih banyak variabel agar didapat hasil penelitian yang lebih komprehensif.

\section{DAFTAR PUSTAKA}

Al Qur'an dan terjemahannya. 2005. Syamil Al-Qur'an. Bandung: PT Syamil Cipta Media.
Arby, Ikhsan, 2017. Fakultas pariwisata Umsb sebagai pusat Pengembangan pendidikan pariwisata syariah

Ansori dan Iswati. 2009. Buku Ajar Metodelogi Penelitian Kuantitatif. Surabaya: Airlangga University Press.

Halim, Abdul. 2004. Manajemen Kevangan Daerah.Yogyakarta: (UPP) AMP YKPN.

Hamjah, N. (2015). Pengaruh Periklanan, Pameran dan Event terhadap peningkatan kesadaran wisatawan dan dampaknya pada minat berkunjung ke destinasi wisata religi di aceh. Jurnal Manajemen, Vol.4, No.2.

Mangkoesoebroto, Guritno. 2001. Ekonomi Publik. BPFE, Yogyakarta.

Mardiasmo. 2000 Membangun Manajemen Kevangan Daerah. Andi. Yogyakarta.

Munajjed, M. (2010). Hakekat Wisata Dalam Islam, Hukum dan Macammacamnya.

https://islamqa.info/id/87846. Diakses pada tanggal 25 Juli 2017.

Pendit, Nyoman S. 2002. IImu Pariwisata: Sebuah Pengantar Perdana, Jakarta: Pradnya Paramita.

Salim, F.B. (2012). Panduan Wisatawan Muslim. Jakarta: Pustaka AlKautsar.

Sammeng, Andi, Mappi. 2001. Cakrawala Pariwisata. Jakarta: Balai Pustaka. 
Islah, et al/Jurnal Ekonomi Syariah Teori dan Terapan Vol. 6 No. 4 April 2019: 658-671; ANALISIS PENGUNJUNG DAN RETRIBUSI (PEDAGANG) KAWASAN WISATA RELIGI SUNAN GIRI TERHADAP PENDAPATAN ASLI DAERAH KABUPATEN GRESIK PERIODE 2011-2016

Samsubar, Saleh. 2003. "Kemampuan Pinjam Daerah Kabupaten dan Kota dilndonesia", Vol. XIV No. 2 Desember 2003, Semarang: Media Ekonomi \& Bisnis.
Sutrisno P.H, 1988, Dasar - Dasar IImU Keuangan Negara, BPFE, Yogyakarta.

Syahriza, R. (2014). Pariwisata Berbasis Syariah (Telaah Makna Kata Sara dan Derivasinya dalam al-Qur'an). Jurnal Human Falah, Vol. 1, No. 2. 